\title{
A vércukorértékek nem feltétlenül jellemzik megfelelően a sejtanyagcsere-állapotot
}

\author{
Simon Kornél dr. ${ }^{1}$. Wittmann István dr. ${ }^{2}$ \\ ${ }^{1}$ Siófoki Kórház-Rendelőintézet, Belgyógyászati Osztály, Siófok \\ ${ }^{2}$ Pécsi Tudományegyetem, Általános Orvostudományi Kar, Klinikai központ, II. Belgyógyászati Klinika, \\ Nephrologiai Centrum, Pécs
}

\begin{abstract}
A szakmai ajánlásokban a normális vércukorérték megvalósítása jelenti a diabetes sikeres kezelését, azaz a diabetes terápiájában az euglykaemia elérése a cél. Ez azt sugallja, hogy a normális vércukorérték normális anyagcsere-állapotot (eumetabolizmust) jelez, míg a hyperglykaemia kóros anyagcsere-állapotot (diszmetabolizmust) jelöl. Az is joggal felvethető, hogy vajon ugyanazon vércukorérték esetén az intracelluláris energiaszolgáltatás biokémiai mechanizmusai azonosak-e, avagy egymástól különböznek? A kérdés megválaszolása céljából a szerzők számos, egymástól eltérő patofiziológiai paraméterekkel jellemezhető klinikai állapotban vizsgálták a rövid távú, valamint a hosszú távú vércukorérték és a sejtanyagcsere jellemzőinek összefüggését az irodalmi adatok alapján. Tanulmányozták ezen összefüggést a micro- és a macroangiopathia patogenezisében, vizsgálták a vércukor és a sejtanyagcsere összefüggésének különbözőségeit 1 -es és 2 -es típusú diabetesben, valamint a vércukor és a myocardium-anyagcsere kapcsolatát akut és krónikus stresszben, továbbá a vércukor és a sejtanyagcsere viszonyát az úgynevezett „áttörési” (breakthrough) jelenségben, valamint a különböző metabolikus promoterek adása esetén. Arra a következtetésre jutottak, hogy az aktuális vércukorérték nagyon különböző mértékben jelzi az aktuális anyagcsere-állapotot. Az euglykaemiás állapot az esetek egy részében egyáltalán nem utal biztonsággal eumetabolizmusra (sejtszintű energiaegyensúlyra), és a hyperglykaemia sem a kóros (sejtszintű energiadeficiens) anyagcsere-állapotot jelzi feltétlenül. Az is megállapítható, hogy ugyanazon aktuális vércukorérték mellett ugyanazon szerv egyidejü anyagcsere-teljesítménye jelentősen különbözhet, továbbá ezen anyagcsere-állapot biokémiai háttérmechanizmusai alapvetően eltérôk lehetnek. Az is megfogalmazható, hogy a tartósan fennálló ugyanazon vércukorérték-tartomány mellett az egyes szervek anyagcsere-állapota jelentősen különbözhet: bizonyos szervek anyagcsere-egyensúlya megtartott, más szervek anyagcsere-deficitje egyidejúleg jelentős lehet. A fenti következtetések arra vezethetők vissza, hogy a vércukorérték valójában egy transzportparaméter, amely az aktuális egyensúlyi állapotot jelzi a szénhidrátraktárakból a vérbe irányuló glükózforgalom, illetve a vérből a szövetekbe irányuló glükózfelvétel között. Az egyensúlyt tartó kétirányú forgalom sebességének ismerete nélkül - pusztán a vércukorértékből - érdemi következtetés alig vonható le a sejtanyagcsere mennyiségi és minőségi jellemzőire vonatkozóan. Orv. Hetil., 2017, 158(11), 409-417.
\end{abstract}

Kulcsszavak: vércukor, sejtanyagcsere, intracelluláris energiatermelés, euglykaemia, hyperglykaemia, eumetabolizmus, diszmetabolizmus, l-es típusú/2-es típusú diabetes mellitus, cardiovascularis kockázat

\section{The blood glucose value not necessarily indicates correctly the cellular metabolic state}

In clinical recommendations the normalized blood glucose level is declared as the main target in therapy of diabetes mellitus, i.e. the achievement of euglycemia is the main therapeutic goal. This approach suggests, that the normal blood glucose value is the marker of the normal carbohydrate metabolism (eumetabolism), and vice versa: hyperglycemia is associated with abnormal metabolism (dysmetabolism). However the question arises, whether identical blood glucose values do reflect the same intracellular biochemical mechanisms? On the basis of data published in the literature authors try to answer these questions by studying the relations between the short/longterm blood glucose level and the cellular metabolism in different clinical settings characterized by divergent pathophysiological parameters. The correlations between blood glucose level and cellular metabolism in development of micro-, and macroangiopathy, in the breakthrough phenomenon, as well as during administration of metabolic promoters, the discrepancies of relation between blood glucose values and cellular metabolism in type 1 , and type 2 diabetes mellitus, 
furthermore association between blood glucose value and myocardial metabolism in acute and chronic stress were analyzed. Authors conclude, that the actual blood glucose values reveal the actual cellular metabolism in a very variable manner: neither euglycemia does mandatorily indicate eumetabolism (balance of cellular energy production), nor hyperglycemia is necessarily a marker of abnormal metabolic state (dept of cellular energy production). Moreover, at the same actual blood glucose level both the metabolic efficacy of the same organ may sharply vary, and the intracellular biochemical machinery could also be very different. In case of the very same longterm blood glucose level the metabolic state of the different organs could be very variable: some organs show an energetically balanced metabolism, while others produce a significant deficit. These inconsistencies between blood glucose level and cellular metabolism can be explained by the fact, that blood glucose value is a transport parameter, reflecting the actual steady state of glucose transport from the carbohydrate pools into the blood, and that from the blood into the tissues. Without knowing the speed of these transports of opposite direction, the blood glucose value per se can not reveal the quantitative and qualitative characteristics of cellular metabolism.

Keywords: blood glucose, cellular metabolism, intracellular energetic pathway, euglycemia, hyperglycemia, eumetabolism, dysmetabolism, type 1, type 2 diabetes mellitus, cardiovascular risk

Simon, K., Wittmann, I. [The blood glucose value not necessarily indicates correctly the cellular metabolic state]. Orv. Hetil., 2017, 158(11), 409-417.

(Beérkezett: 2016. december 6.; elfogadva: 2017. január 24.)

\begin{abstract}
Rövidítések
AMI = akut myocardialis infarctus; ATP-termelés = adenozintrifoszfát-termelés; $\mathrm{CP} / \mathrm{ATP}$ arány $=$ kreatin-foszfát /adenozintrifoszfát hányados; $\mathrm{CRP}=\mathrm{C}$-reaktív protein $; \mathrm{GIK}$-oldat $=$ glükóz-inzulin-kálium; GLP-1 = glükagonszerú peptid-1; GLUT-4 = glükóztranszporter-4; $\operatorname{IgA}=$ immungloblin- $\mathrm{A} ; \operatorname{IgE}=$ immunglobulin-E; PCI = percutan coronariaintervenció; PPAR = peroxiszómaproliferációt aktiváló receptor; RAS = renin-angiotenzin rendszer; TNF-alfa $=$ tumornekrózis-faktor-alfa
\end{abstract}

A szakmai ajánlásokban a diabeteses betegek akut coronariaszindrómájának, illetve szívelégtelenségének kezelésében a „diabetesspecifikus” üzenet az euglykaemiára való törekvés [1]. Ez azt jelenti, hogy a diabetes terápiájában a normális vércukorérték megvalósítása, az euglykaemia elérése a cél. Ez azt is sugallja, hogy a normális vércukorérték normális sejtanyagcsere-állapotot jelez, vagyis az euglykaemia eumetabolizmust - és megfordítva -, a hyperglykaemia pedig kóros sejtanyagcsere-állapotot jelöl. Mennyiben tekinthetô ezen álláspont konzekvensnek?

Az alábbi kérdések fogalmazhatók meg. Az euglykaemia valóban azt jelenti, hogy a sejtszintü energiatermelő, biokémiai folyamatok energetikai egyensúlyt biztosítanak? További kérdés az is, hogy az adott energiaegyenleget eredményező biokémiai reakcióláncolat egyes elemei: az anaerob glikolízis, az aerob glükózoxidáció, a terminális oxidáció, az oxidatív foszforilálás, valamint a végeredményt képező makroerg foszfátszintézis egymáshoz viszonyított részvételi arányai változatlanok-e, avagy jelentősen eltérőek-e ugyanazon vércukorérték esetén? Másképpen fogalmazva: ugyanazon vércukorérték fennállásakor az intracelluláris energiaszolgáltatás biokémiai mechanizmusai azonosak-e, avagy egymástól különböznek-e?
Az anyagcsere kifejezés alatt a sejt ezen energiaszolgáltató biokémiai folyamatainak láncolatát értjük, amelynek eredménye a sejt energiaállapotát megjelenítő $\mathrm{CP} / \mathrm{ATP}$ arány. Nem vitatható, hogy a legkülönbözőbb kórállapotok, legfóképp az úgynevezett anyagcsere-betegségek, így a diabetes is - eltérő mechanizmusokkal és eltérő szervi manifesztációkkal - az érintett szervek sejtjeinek energetikai egyensúlyát elónytelenül befolyásolják. Az ily értelemben vett sejtanyagcsere-károsodás képezi a szerteágazó klinikai tünettan közös alapját.

Értelmezésünk szerint az eumetabolizmus kifejezés azt jelöli, amikor az energiaszolgáltató intracelluláris biokémiai láncolat múködésének eredményeképp a sejt energetikai egyensúlya megtartott, azaz a CP/ATP arány normális. A diszmetabolizmus kifejezés alatt az eumetabolizmus hiányát értjük, amikor az energiaszolgáltató mechanizmusok diszfunkciójának következtében a sejten belüli normális CP/ATP arány már nem képes megvalósulni, vagy ha igen, akkor a „terheléssel” indukálható metabolikus rezerv teljesítmény - a normálishoz képest már csökkentnek mutatkozik.

A kérdés megválaszolása céljából egy sor eltérő patofiziológiai paraméterekkel jellemezhetó klinikai állapotban vizsgáltuk az aktuális (rövid időtartamú: óra, nap, hét), illetve a tartós (hosszú időtartamú: hónap, év) vércukorérték és a sejtanyagcsere összefüggésének szorosságát.

\section{A hyperglykaemia és a sejtanyagcsere, valamint az inzulinkezelés és a sejtanyagcsere összefüggése}

A DIGAMI vizsgálat bizonyította, hogy cukorbetegek infarktusában - illetve az azt követően - alkalmazott inzulinkezelés a túlélést jelentősen javította [2]. A DIGAMI 
arra is adatot szolgáltatott, hogy minél magasabb a diabeteses infarktusban szenvedő betegek felvételkor észlelt vércukorértéke, annál nagyobb mérvű az inzulinnal elérhető túlélésjavulás [2], azaz minél kifejezettebb a hyperglykaemiával kapcsolatba hozható myocardiumanyagcsere-zavar, annál hatásosabb az inzulinkezelés. Más szóval, minél jelentősebb a vércukor inzulinnal történő rendezése, annál kifejezettebb az anyagcsere-javulás.

A DIGAMI következtetéseit többen kétségbe vonják, hivatkozva arra, hogy a DIGAMI-2 tanulmány [3] eredményei nem szolgáltattak megerősítő adatokat. Ez a kétség azonban azzal is magyarázható, hogy ebben a vizsgálatban sem az első 24 órában, sem az ezt követő időszakban az inzulinnal kezelt csoport szénhidrátanyagcsere-állapota nem különbözött szignifikánsan a kontrollcsoport értékeitől.

A vércukor és a sejtanyagcsere szoros kapcsolatát látszik erôsíteni azon észlelés, miszerint az átmeneti stresszhyperglykaemiát produkáló infarktusos betegek túlélése jelentősen rosszabbnak bizonyult az infarktus akut szakában is az euglykaemiás betegekéhez képest [4]. Hasonlóképpen, az akutan végzett PCI során észlelt magasabb vércukorértékek is károsan befolyásolták a betegek életkilátásait [5]. Ezek az adatok a hyperglykaemia és az anyagcserezavar összefüggése mellett szólnak.

A diabeteses betegek bypassmütétje során 12 órán át alkalmazott GIK-oldat szignifikánsan javította a hosszú távú túlélést, utalva arra, hogy a mütét során jelentkező ischaemiás és reperfúziós eredetű anyagcserezavart (ischaemiás diszmetabolizmust) az egyidejű inzulin-glükóz kezelés mérsékelte [6].

Meglepő volt az a megfigyelés, hogy szeptikus, súlyos állapotú betegek túlélését a konvencionális kezelés mellett alkalmazott GIK-oldat meghosszabbította, feltehetően azáltal, hogy a toxikus eredetú sokszervi anyagcserezavart (toxikus diszmetabolizmus) a kezelés által előidézett fokozott szöveti glükózfelvétel és a következményes intracelluláris anyagcsere-javulás enyhíteni tudta [7]. Megjegyzendő, hogy ezen betegek mintegy 70\%ában stressz-hyperglykaemiát is lehetett dokumentálni.

A CREATE ECLA [8] tanulmányban több mint 20000 betegen vizsgálták az akut szakban 24 órán át adott GIK-oldat hatását infarktusos betegek túlélésére. Elméletileg a GIK-oldat előnyös effektusa akkor várható, ha a fenyegetett szívizomterület károsodása még csak reverzibilis (az időablak kisebb, mint egy óra, azaz a kezeléstől a nekrózis késleltetése remélhető), másrészt akkor, ha a GIK-oldat adását sikeres reperfúzió követi, hiszen a keringés helyreállítása nélkül a nekrózis elkerülhetetlenül bekövetkezik. A sikeres reperfúzió esetén alkalmazott GIK-oldattól a reperfúziós ártalom mérséklése várható. Tekintettel arra, hogy a szóban forgó vizsgálatban az időablak jóval nagyobb (3,85 óra) volt, továbbá a GIKoldat alkalmazása az esetek döntő többségében a reperfúziós intervenció után történt (4,7 órával a tünetek fellépte után), nem meglepő, hogy sem a halálozásban, sem az egyéb klinikai paraméterekben nem tudták kimutatni a GIK-oldat előnyös hatását. Amennyiben a vizsgálatban részt vevő azon betegek adatait analizálták, akiknél az időablak egy óránál rövidebb volt, illetve a GIK-oldat adását sikeres reperfúzió követte, akkor az intervenció hatásosnak bizonyult [9]. Ezen adatok a GIK-oldat metabolikus promoter hatását támogatják: az egyidejü glükóz- és inzulinbevitel - a vércukorértéktől függetlenül javítani képes a sejtanyagcserét.

Az ellentmondó adatokra való hivatkozással a GIK-oldat akut coronariaszindrómában történő alkalmazását illetően jelenleg nincs egyértelmű ajánlás.

\section{Mire utal az „áttörési” inzulinkezelés („breakthrough”)?}

A 2-es típusú diabetesesek krónikus hyperglykaemiájában alkalmazott néhány hetes intenzív (konzervatív vagy pumpa) inzulinkezeléssel a krónikus anyagcsere-károsodást átmenetileg vissza lehet fordítani [10]. Ennek során a károsodott inzulinérzékeny szövetek állapota (máj, zsír, vázizom stb.) és a szintén kóros béta-sejt-funkció javul. Kimutatható, hogy az inzulinrezisztencia, a hepaticus glükózkiáramlás csökken, és az inzulinszekréció növekszik. Feltételezik, hogy a kezelés az intracelluláris jelátviteli folyamatokat korrigálja, vagyis az inzulinkezeléssel elért „áttörés” elönyösen tudja befolyásolni a sejten belüli kóros biokémiai folyamatokat [11].

\section{A vércukor és az anyagcsere összefüggése a microangiopathia patogenezisében}

A klasszikus patogenetikai elképzelés szerint a cardiovascularis rizikófaktorok (köztük a vércukor) tartós emelkedése endotheldiszfunkcióhoz, ez cardiovascularis diszfunkcióhoz, majd strukturális remodellációhoz vezet a szívben, a macrovascularis és a microvascularis szegmensben egyaránt [12].

Jól ismert, hogy a coronariaágban levő organikus szûkület - az ismétlódő fizikai terhelések során - a poststenoticus érrendszer által ellátott myocardiumban repetitív ischaemiás attakokat eredményez. Az ezek során megjelenő, ismétlődő metabolikus dekompenzációs epizódok pedig - mintegy ellenreakció gyanánt - a kollaterális microvascularis hálózat kialakulását eredményezik, ugyanis a mikrocirkuláció-célszerv egységben a célszerv anyagcsere-egyensúlyának megtartása a teleologikus prioritás, míg a vasculatura a „kiszolgáló szerv”.

Joggal vethető fel, hogy a diabeteses anyagcserezavarban szenvedő szervekben is - a nem diabeteses állapothoz viszonyítva - gyakrabban jönnek létre anyagcseredekompenzációs állapotok, amelyek a mikrocirkulációban „célszerú” adaptációt: vazoregeneratív reakciót váltanak ki. Ezen patogenetikai elképzeléssel jól egybevág - egyrészt - az, hogy a mikrocirkulációs adaptáció (azaz a microangiopathia) éppen a diabetesben a legkifejezettebb. Másrészt az is támogatni látszik e feltételezést, 
hogy a microangiopathia azon szervekben (retina, idegrendszer, vese) a legkifejezettebb, amelyek anyagcsereaktivitása a legnagyobb, azaz a diabeteses anyagcserezavar okozta metabolikus deficit kialakulása ezen szervekben a leggyakoribb, illetve legnagyobb mértékú. Példaként említhető, hogy a retina anyagcsere-egyensúlyát az anaerob és aerob folyamatok állandó, együttes, teljes aktivitása tudja csak biztosítani [13].

A fenti összefüggést erősíti az a tapasztalat, miszerint minél kifejezettebb a hyperglykaemia, annál jelentősebb a microangiopathia.

A diabetesre jellemző anyagcsereromlás és a vele együtt járó hyperglykaemia ok-okozati kapcsolata kézenfekvőnek látszik. l-es típusú diabetesben a sejtanyagcsere-zavar primer oka az inzulinhiány, míg a 2-es típusú diabetesben, metabolikus szindrómában feltételezett sejtanyagcsere-zavar pontos természete nem tisztázott, de a relatív inzulinhiány okozta diszmetabolizmus is oki tényező (lásd alább).

A vércukorszint-emelkedés és a következményes anyagcserezavar összefüggése sem elvethető: nem diabetesesekben glükózinfúzióval létrehozott tartós hyperglykaemia másodlagos anyagcserezavart (úgynevezett „glükotoxicitást") hoz létre [14].

A hyperglykaemia és a sejtanyagcsere-zavar kapcsolatát jelzi a hyperglykaemiás diszmetabolizmus kifejezés.

A fent vázolt mechanizmus mellett szólnak azon evidenciák, amelyek szerint a hyperglykaemia (azaz a hyperglykaemiás diszmetabolizmus) mérséklése viszonylag gyorsan és kifejezetten megnyilvánul a microangiopathia javulásában, és csak jóval később és bizonytalanabbul mérhető a macroangiopathia regressziójában $[15,16]$.

\section{A vércukor és az anyagcsere összefüggése a macroangiopathia patogenezisében}

Jól ismert tény, hogy l-es típusú diabetesben a hyperglykaemia évtizedekig jelen lehet anélkül, hogy klinikailag jelentős macroangiopathia kimutatható lenne $[17,18]$. A klinikailag észlelhető macroangiopathia pedig - az esetek döntő többségében - a diabeteses nephropathia súlyosbodásával - és az ezzel együtt járó magas vérnyomás és dyslipidaemia megjelenésével - esik egybe [18, 19].

A 2-es típusú diabetesben már jóval a tartós hyperglykaemia megjelenése előtt kifejlődik a klinikai szövődményeket (AMI, stroke, alsó végtagi érbetegség) is okozó macroangiopathia $[17,18,20,21]$. A diabetes két formája tehát erôsen eltérő módon viselkedik a macroangiopathia kialakulási idejének tekintetében. A 2-es típusban a vércukor normális - vagy alig emelkedett értékeihez már igen kifejezett atheromatosis tartozhat, míg l-es típusban rendszerint a vércukorértékek tartós és markáns emelkedése sem eredményez jelentős macroangiopathiát.

Mindezen megfigyelések egyértelmúen utalnak arra, hogy sem az l-es, sem a 2-es típusú diabetesben nem a vércukor-emelkedés és a vele kapcsolható szöveti anyagcserezavar a döntő tényező az atheromatosis kialakulásában.

Ha az 1-es és 2-es típusú diabetesben észlelhető macroangiopathia létrejötte a betegség természetes lefolyása során - időbeli megjelenését tekintve - jelentősen eltér, és ha ezen eltérés nem magyarázható a vércukorértékek kronológiai alakulásával, akkor olyan tényezőkben kell keresni a magyarázatot, amelyek nem a két betegség azonosságát (azaz a vércukor-emelkedést), hanem a különbözőségét (a cardiovascularis rizikófaktorok előfordulásában, valamint a sejtanyagcsere-zavar természetében megmutatkozó eltéréseket) teszik vizsgálódás tárgyává. Ezért mondják jó néhányan, hogy a 2-es típusú diabetes elnevezés nem a lényeget megragadó megjelölés [22].

Az elmondottakból megállapítható, hogy a hyperglykaemia és a hozzá kapcsolható szöveti anyagcserezavar (hyperglykaemiás diszmetabolizmus) sokkal jelentősebb szerepet játszik a microangiopathia, mint a macroangiopathia kialakulásában. A 2-es típusú diabetesre jellemző sejtanyagcsere-zavar kitüntetetten érinti a macrovascularis szegmenst: ennek előbb diszfunkcióját, majd morfológiai remodellációját létrehozva okoz klinikai tüneteket, míg az 1-es típusú diabetesre jellemző hyperglykaemiás diszmetabolizmus hosszú ideig microangiopathiás szövődményekben nyilvánul meg.

Mindez arra utal, hogy az l-es típusú és a 2-es típusú diabetesre jellemző anyagcserezavar természete egymástól jelentősen különbözik. Ezen egymástól eltérő kétféle diszmetabolizmus természetét az alábbiakban taglaljuk.

\section{A vércukor és a szöveti anyagcserezavar összefüggésének különbözősége 1-es és 2 -es típusú diabetesben}

Jól dokumentált 2-es típusú diabetesben a postprandialis inzulinelválasztás kóros volta: a hyperinsulinaemia mellett már igen korán (2-es típusú cukorbetegek hozzátartozóiban már az euglykaemiás fázisban) [22] kimutatható a pulzatilis inzulinelválasztás hiánya, illetve a postprandialis korai inzulinelválasztás csökkent mértéke, amelyet kórosan magas és afiziológiásan elhúzódó inzulinelválasztás követ [23-25]. A vércukorszint jó ideig nem emelkedik, de a glükózanyagcserében már eltérések jelennek meg. Példaként említhető, hogy a harántcsíkolt izom GLUT-4-mediált glükóztranszportjának csökkenése 2-es típusú cukorbetegek euglykaemiás rokonaiban már kimutatható [26], ugyanígy a glikogénszintézis és a glükózoxidáció csökkent kapacitása, valamint a fokozott laktátképződési hajlam $[24,25]$, továbbá a postprandialis glükagonszekréció kóros fokozódása is dokumentált [24, 25]. A bonyolult képhez hozzá tartozik az adipocytákból származó hormonok (TNF-alfa, leptin, rezisztin, adiponektin) nem pontosan ismert anyagcserehatásainak megváltozása, ugyanis ezen hormonok szintjei a normálistól jelentősen különböznek [26-29]. Mindez együtt 
jól mutatja, hogy a 2-es típusú diabetes már igen korai szakában az elsődleges és másodlagos jelátviteli rendszer komplex zavarával kell számolni, amely zavar azonban nem vezet szükségszerúen vércukorszint-változáshoz, de szükségszerűen megváltoztatja a sejten belüli energiaszolgáltató biokémiai mechanizmusokat [11].

Például 2-es típusú diabetesben, metabolikus szindrómában a mitokondriumok indukálható metabolikus teljesítménye csökkent, aminek eredményeképp az intracelluláris CP/ATP arány redukálódik [30-33]. Az indukálható kontraktilis rezerv is csökken, aminek oka a citoszol kalciumion-oszcilláció amplitúdójának csökkent volta, illetve az excitáció-kontrakciós kapcsolódás sérülése [30-33]. Centrális obesitasban szenvedő betegek cardiovascularis kockázata nagyobb, mint a coronaria-rizikófaktorok tekintetében megegyező, de nem elhízott betegek kockázata [34]. Ezen adat a centrális obesitas önálló cardiovascularis rizikófaktor természete mellett szól, sőt - a cardiovascularis rizikófaktorok egyezősége miatt - a centrális obesitasban megjelenő független kockázati tényező (sejtanyagcsere-zavar) léte mellett szól, ami a normális vércukorérték mellett is jelen lehet. Ezt a típusú anyagcserezavart jelöli az euglykaemiás diszmetabolizmus kifejezés.

Klinikai adatok is bizonyítják, hogy l-es és 2-es típusú diabetesben és metabolikus szindrómában korán károsodik a legnagyobb energiaigényú szívciklus, a diasztolé [30-32, 35]. Terheléses echokardiográfiás mérésekkel igazolható, hogy a diasztolé kezdetén a mitralis szájadékon át történő beáramlás sebessége csökken, illetve a diasztolés telődéshez szükséges nyomás megnő a nem a diabeteses egyedekhez képest [31]. Ugyanígy demonstrálható az is, hogy a terhelés során, a szisztolé alatt az anulus fibrosus mozgássebessége, illetve annak amplitúdója is csökken [31], ugyanúgy, mint a terhelés alatti ejekciósfrakció-növekedés mértéke is kisebb az egészséges kontrollokhoz képest . Régi megfigyelés, hogy diabetesben a periinfarktusos zóna kompenzáló hiperkinézise csökken a nem diabetesesekhez képest [36, 37], ami klinikailag is igazolja, hogy a diabeteses myocardium indukálható funkcionális (metabolikus) tartaléka beszúküul. A GUSTO-I adatai [37] igazolták, hogy akut infarktuson átesett diabeteses betegek egy hónapos túlélése roszszabb, mint a nem diabeteses betegeké, noha a klinikai adatok (cardiovascularis rizikófaktorok, kísérő betegségek, a koronarográfiás kép) a két betegcsoportban azonosak voltak. Ezen megfigyelés nagy valószínúséggel a diabeteses anyagcserezavar önálló cardiovascularis kockázati szerepére utal, amely rizikótényező hozzáadódik az úgynevezett ischaemiás kóreredetű cardiovascularis kockázathoz [38].

A fenti adatok 1-es és 2-es típusú diabetesben szenvedő „kevert betegcsoportra” vonatkoznak, ami arra utal, hogy mindkét típusú diabetesben egyaránt sejtanyagcsere-zavar van jelen. A két típusú diszmetabolizmus természete különbözik, de mindkettő a metabolikus rezerv kapacitás beszúkülését eredményezi.
A SAHS [39] adatai szerint a cardiovascularis mortalitás kockázata férfiakban és nőkben egyaránt szignifikánsan megnövekszik a metabolikus szindróma jelenlétében (diabetes nélkül), a 2-es típusú diabetes mellitus jelenlétében (metabolikus szindróma nélkül), amely kockázatnövekedés a metabolikus szindróma és a 2-es típusú diabetes mellitus együttes előfordulásakor - különösen nőkben - ugrásszerüen fokozódik. A metabolikus szindróma kizárólagos jelenléte (2-es típusú diabetes mellitus nélkül) az euglykaemiás diszmetabolizmus, a 2-es típusú diabetes mellitus egyedüli jelenléte (metabolikus szindróma nélkül) a hyperglykaemiás diszmetabolizmus, a kettő (metabolikus szindróma és 2-es típusú diabetes) együttes jelenléte pedig az euglykaemiás és hyperglykaemiás diszmetabolizmus által együttesen képviselt cardiovascularis rizikót hordozza.

A fentiek azt jelentik, hogy a 2-es típusú cukorbetegjelöltekben már akkor számolni kell jelentős sejtanyagcsere-zavarral, amikor a vércukor normális. Lényeges kihangsúlyozni, hogy a 2-es típusú cukorbetegségre jellemző fenti komplex zavar egyáltalán nem rendelhető hozzá az 1-es típusban mért identikus vércukorértékekhez, sôt a jól beállított l-es típusú cukorbetegre az úgynevezett „antiatherogen” anyagcsereclustert tartják jellemzőnek [19]. Mindez arra utal, hogy a normális vagy nem jelentősen emelkedett vércukor mellett is jelentős anyagcserezavar és cardiovascularis kockázatfokozódás lehet jelen, és megfordítva, a hyperglykaemia - önmagában - nem feltétlenül jelent „arányos” cardiovascularis kockázatfokozódást.

Az elmondottakból az következik, hogy nem feltétlenül a vércukor önmaga jelenti a fokozott cardiovascularis kockázatot, hanem az aktuális (akár normális) vércukorértékkel együtt egyidejűleg jelen lévő magas vérnyomás, hyperlipidaemia, illetve haemostasiszavar. Mindezen tényezők együttesen eredményezik az elsődleges és a másodlagos messanger rendszer megváltozását, és a következményes intracelluláris biokémiai mechanizmusok diszfunkcióját, azaz diszmetabolizmust.

Megállapítható tehát, hogy normoglykaemia mellett is jelen lehet az anyagcserezavar, másrészt a hyperglykaemia tartós mérséklése javítja, de nem feltétlenül küszöböli ki az anyagcserezavart, sem pedig a cardiovascularis szövődmények kialakulását.

\section{A vércukor és a myocardium-anyagcsere összefüggése akut és krónikus stresszben}

Az akut és a krónikus stressz hemodinamikai, metabolikus, illetve morfológiai következményei jelentősen különböznek egymástól (1. ábra). Az akut stresszhelyzetben megjelenő myocardiumváltozások az alábbiakkal jellemezhetők: a keringő katecholaminszaporulat hatására a coronariaátáramlás megnő, a myocardium-anyagcsere fokozódik: a nyugalmi állapotra jellemző szabadzsírsav-égetés helyett a glükózoxidáció kerül túlsúlyba, a mitokondriumok oxigénfelhasználása, ATP-termelése 
Krónikus stressz, káros életmód ${ }^{1}$

(KEZELÉS: stresszoldás, életmódrendezés)

\section{$\downarrow$}

Intracelluláris oxidatív stressz

(KEZELÉS: jelenleg nincs specifikus kezelés)

$$
\downarrow
$$

Intracelluláris regulációs (jelátviteli) zavar

(KEZELÉS: jelenleg nincs specifikus kezelés)

$$
\downarrow
$$

Euglykaemiás diszmetabolizmus ${ }^{2}$

(KEZELÉS: adekvát praediabetes- és antiatheroscleroticus kezelés)

$$
\downarrow
$$

Hyperglykaemiás diszmetabolizmus ${ }^{3}$

(KEZELÉS: adekvát antidiabetikus és antiatheroscleroticus kezelés)

\section{Progresszió $^{4}$}

(KEZELÉS: adekvát antidiabetikus és antiatheroscleroticus kezelés, akut esetben áttörési inzulinkezelés)

\section{$\downarrow$}

\section{Szervi elégtelenség ${ }^{5}$}

(KEZELÉS: krónikus inzulinkezelés és adekvát szervi támogatás: szervtranszplantáció, dialízis stb.)

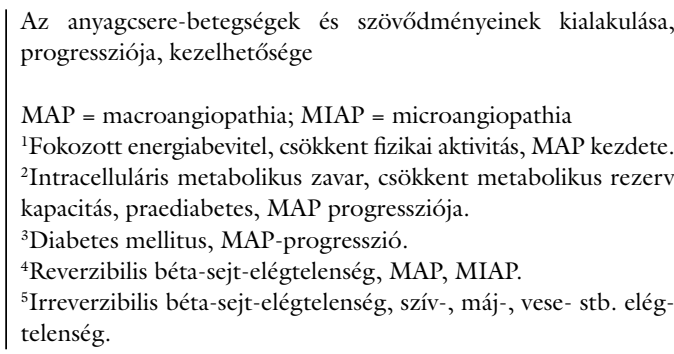

fokozódik, az anaerob glikolízis is aktiválódik, a kontraktilitás, a szívteljesítmény (frekvencia, verővolumen) megnő [30, 40-42]. Összességében a myocardiumperfúzió, az anyagcsere-teljesítmény, a szívmunka egyaránt fokozódik.

Repetitív stressz esetén a perfúzió további tartalékokat képez (kollaterális érújdonképzés), az indukálható anyagcsere-teljesítmény tovább nő (a nyugalmi szabadzsírsav-oxidáció aránya fokozódik, az inzulinérzékenység, a terhelés során bekövetkező zsírsavról glükózoxidációra való áttérés mértéke, a glikogénraktárak mennyisége megnő). A szívizom morfológiai átépülése (bal kamrai hipertrófia megjelenése) szintén a nagyobb szívteljesítményt szolgálja [41, 42].

A krónikus stressz esetén a myocardium ezen jótékony hatású adaptációja azonban egy idő után maladaptációba megy át, amely állapot a krónikus szívelégtelenség kialakulását eredményezi. Ezen állapot az úgynevezett katecholamindeszenzitizációval jellemezhető: a myocardium béta-1 receptorai „downregulálódnak”, a receptoraktiváció csak extrém dózisú katecholaminnal váltható ki
$[43,44]$. A myocardium-anyagcserében is változások jönnek létre: a katecholaminok által kiváltott szabadzsírsav-mobilizáció, az inkomplett szabadzsírsav-oxidáció a mitokondriumfunkció zavarát idézi elő (úgynevezett toxikus szabadzsírsav-anyagcseretermékek és „uncoupling” proteinek felszaporodása jön létre), ami miatt az ATP-termelés csökken, az aerob energia-szolgáltatás teljesítménye csökken, amit az anaeorob glikolízis igyekszik kompenzálni [45, 46]. Mindez az úgynevezett oxidatívstressz-állapottal jellemezhető, ami az indukálható anyagcsere-kapacitás beszúkülését eredményezi (metabolikus remodelling). A sejtanyagcsere ezen típusú zavarát stresszasszociált diszmetabolizmus elnevezéssel lehet illetni [38]. A fenti anyagcsere-változásokkal összefüggésben a myocardium mechanikus funkciója is romlik (diasztolés és szisztolés diszfunkció jelenik meg), illetve a bal kamra jellegzetes morfológiai átalakuláson megy keresztül, úgynevezett dilatatív bal kamrai remodelláció jön létre $[43,44]$.

Mindez arra utal, hogy az akut, a repetitív, a krónikus stressz - noha a vércukorértékek nem feltétlenül különböznek - jelentősen eltérő myocardiumanyagcsere-állapotot takarnak. Más szóval: az anyagcsere-állapotra a vércukorérték nem tartalmaz megbízható információt.

A diabetes patofiziológiájából következik, hogy ezen állapot jellemzője a hyperglykaemiára való hajlam. Ezzel szemben a hypoglykaemiát a diabeteses beteg jó ideig képes sikerrel akár elhárítani - vagy legalábbis csökkenteni - az úgynevezett ellenregulációs mechanizmusokkal. Ez azt jelenti, hogy ugyanazon vércukorértékhez a legkülönbözőbb aktivitású ellenregulációs hormonszintek (katecholamin, kortikoszteroidok, növekedési hormon, glükagon, citokinek stb.) tartozhatnak. Nyilvánvaló, hogy ezek a jelentősen eltérő endokrin állapotok - az egyidejű azonos vércukorértékek ellenére - nem eredményezhetnek azonos sejtanyagcsere-állapotot. Más szóval, az azonos vércukorérték „mögött” teljesen eltérő metabolikus állapotok húzódnak meg, azaz a vércukorérték nem feltétlenül releváns paraméter az aktuális metabolizmus felfedésében.

Jól dokumentált, hogy a rövid távot teljesítő sprinter és a maratoni futó vércukorértékei vagy normálisak, vagy némileg emelkedettek. Ezen vércukorértékek mögött mindkét esetben fokozott anyagcsere-teljesítmény húzódik meg. Más szóval: ebben az esetben az esetleges hyperglykaemia tehát nem anyagcsere-károsodást, azaz csökkent anyagcsere-teljesítményt, hanem annak ellenkezőjét: fokozott anyagcsere-teljesítményt „takar”. Ezen fokozott anyagcsere-teljesítmény energiaszükségletét a rövidtávfutó esetében a makroergfoszfát-tartalékok (kreatinfoszfát és ATP) akut depléciója, valamint az anaerob glikolízis aktivációja együttesen szolgáltatja, míg a maratoni futó esetében az energia fó szolgáltatója a citrátkör aerob anyagcsere-folyamata, ahol a fó energiaforrás nem a glükóz, hanem a szabad zsírsav égetése. Mindez egyértelmúen arra utal, hogy ugyanazon vércukorérték mögött teljesen különböző, egymástól eltérő anyagcse- 
re-mechanizmusok múködnek, azaz a vércukorérték önmagában - ismételten - nem tekinthető releváns anyagcsere-referensnek.

\section{A vércukor és a szöveti anyagcsere összefüggése a metabolikus promoterek ismeretében}

Az UKPDS [21, 47] szerzői érdekes megfigyelésről számoltak be. A metforminnal kezelt 2-es típusú diabeteses betegek klinikai kimenetele szignifikánsan jobb volt, mint az inzulinnal vagy az egyéb per os antidiabetikummal kezelt egyedekben, noha az „anyagcserehelyzet” (tartós vércukorérték) nem különbözött a fenti betegcsoportokban. A metformin ezen előnyös hatása tehát nem a jobb vércukorértékekhez, hanem valamely egyéb mechanizmushoz (inzulinrezisztencia csökkentése, anyagcsere-promóció) volt hozzárendelhetô [48]. A vércukorérték tehát ismét nem nevezhető megbízható paraméternek az aktuális anyagcsere-állapot megítélése szempontjából.

A metabolikus promoterek alkalmazása egy új lehetséges hatásmechanizmus lehetőségére utal. A metformin mellett egyéb hivatkozások is citálhatók: az akarbóz amellett, hogy a glükózfelszívódást gátolja - az inkretinek (GLP-1) aktiválásával inzulinszekréciót fokozó hatással is rendelkezik [48], a postprandialis hyperglykaemia mérséklésével pedig előnyös anyagcsere-módosulások jönnek létre [48-50]. A fibrátok, a tiazolidindionok, ső́t a statinok is - a PPAR-magreceptorokon történő hatásukkal - alapvetố celluláris metabolikus folyamatokat befolyásolnak [48, 51]. Ez felveti annak a lehetőségét, hogy a metabolikus szindrómában feltételezett sejtanyagcsere-zavarra fejtsenek ki jótékony hatást $[48,52,53]$. Ezen új megközelítésre irányítják a figyelmet a fenti biztató adatok, de jelenleg még nem rendelkezünk meggyőző bizonyítékokkal.

Mindemellett e helyütt is hangsúlyozni kell, hogy az euglykaemiára való törekvés változatlanul hatásos fegyver a diabetes mellitus kezelésében, és - ezáltal - fontos tényezője a cardiovascularis rizikó csökkentésének is [54].

\section{Következtetések}

Az elmondottakat összefoglalva kijelenthető, hogy az aktuális vércukorérték nagyon különböző mértékben jelzi az aktuális anyagcsere-állapotot. Az euglykaemiás állapot az esetek egy részében egyáltalán nem utal biztonsággal eumetabolizmusra (sejtszintứ energiaegyensúlyra), és a hyperglykaemia sem a kóros (sejtszintú energiadeficiens) anyagcsere-állapotot jelzi feltétlenül.

$\mathrm{Az}$ is megállapítható, hogy ugyanazon aktuális vércukorérték mellett ugyanazon szerv egyidejü anyagcsereteljesítménye nemcsak, hogy jelentôsen különbözhet, hanem ezen anyagesere-állapot biokémiai háttérmechanizmusai is alapvetően eltérók lehetnek.

$\mathrm{Az}$ is megfogalmazható, hogy a tartósan fennálló ugyanazon vércukortartomány mellett az egyes szervek anyagcsere-állapota jelentősen különbözhet: bizonyos szervek anyagcsere-egyensúlya megtartott, más szervek anyagcsere-deficitje egyidejúleg jelentôs lehet.

A diabetesre jellemző akcelerált öregedés a legnagyobb anyagcsere-aktivitású szervekben (retina, agy, szív, vese) jelenik meg. Mivel mindezen szervek megkülönböztetett sorsa ugyanazon vércukortartomány mellett alakul ki, ezért kijelenthetô, hogy ugyanazon tartós vércukortartomány nem jelzi az egyes szervek nagyon is különböző anyagcserehelyzetét, sem a funkcionális, sem a morfológiai állapotban fellelhető eltérőségeket. A vércukorértékek tehát nem nevezhetők a különböző szervek állapotára általában jellemző anyagcsere-paraméternek.

A fenti megállapítások nem meglepőek, ha tekintetbe vesszük azon nyilvánvaló tényt, hogy a vércukorérték valójában egy transzportparaméter. A keringésnek - mint kiszolgáló-szállító rendszernek - teleologikus értelme a szervek, a szövetek anyagcseréjéhez szükséges komponensek célba juttatása. Ezen transzportrendszerból, a vérből vett minták kémiai analízisébőll próbálunk következtetést levonni az egyes szervek anyagcsere-állapotára vonatkozóan.

Általános biológiai érvénnyel bíró megállapítás, hogy a keringési (transzport-) rendszerek lényegesen különböző paraméterekkel jellemezhetók, mint a velük szoros kapcsolatban álló szöveti kompartmenek. Példaként említhető a keringő vs. szöveti IgA és IgE, a humorális és a szöveti RAS-rendszer, a legkülönbözőbb hormonok, a CRP, a lipidek, az aminosavak, az anorganikus ionok stb. humorális és szöveti rendszerei.

Hasonlóképp tekinthetünk a különböző szervek (elsősorban a máj, a harántcsíkolt izomszövet) szénhidrátraktáraira, amelyek a keringési rendszeren keresztül biztosítják a különböző szervek - egymástól eltérő mértékủ és mechanizmusú - glükózfelvételét. Utóbbira példaként említhetô a máj, a zsírszövet, a szívizom, a harántcsíkolt izomzat - a többi szövetektől eltérő - glükóztranszportsajátsága (úgynevezett inzulindependens glükózfelvétel).

A vércukor valójában egy egyensúlyi állapotot jelöl - egyfelől - a szénhidrátraktárakból a vérbe irányuló forgalom és - másfelŏl - a vérből a szövetekbe irányuló glükóztranszport között. Az egyensúlyt tartó kétirányú forgalom sebességének ismerete nélkül azonban - pusztán a vércukorértékből - érdemi következtetés alig vonható le az egyes szervek aktuális glükózfelvételére és még kevésbé - a sejtanyagesere állapotára vonatkozóan. Más szóval, az aktuális vércukorérték és az aktuális anyagcsere-aktivitás összefüggése erősen megkérdőjelezhető. A ténylegesen meglévó metabolikus aktivitást - annak az egész szervezetre érvényes globális mértékét sokkal inkább kifejezné az „össz-szöveti” glükózfelvétel (glucose disposal) ismerete. 
Ami pedig az egyes szervek aktuális anyagcsere-állapotának valódi megítélését (beleértve az úgynevezett metabolikus rezerv kapacitást is) illeti, a bioimaging módszerekkel történő mérésektől remélhetünk objektív adatokat [55].

Anyagi támogatás: A közlemény megírása anyagi támogatásban nem részesült.

Szerzői munkamegosztás: A hipotézis kidolgozása, a kézirat megszövegezése mindkét szerző közös munkája. A cikk végleges változatát a szerzők elolvasták és jóváhagyták.

Érdekeltségek: A szerzőknek nincsenek érdekeltségeik.

\section{Irodalom}

[1] Rydén, L., Grant, P. J., Anker, S. D., et al.: ESC Guidelines on diabetes, pre-diabetes, and cardiovascular diseases developed in collaboration with the EASD: the Task Force on diabetes, prediabetes, and cardiovascular diseases of the European Society of Cardiology (ESC) and developed in collaboration with the European Association for the Study of Diabetes (EASD). Eur. Heart J., 2015, 34(39), 3035-3087.

[2] Malmberg, K., for the DIGAMI (Diabetes Mellitus Insulin Glucose Infusion in Acute Myocardial Infarction) Study Group: Prospective randomised study of intensive insulin treatment on long term survival after myocardial infarction in patients with diabetes mellitus. BMJ, 1997, 314(7093), 1512-1515.

[3] Malmberg, K., Ryden, L., Wedel, H., et al., for the DIGAMI 2 Investigators: Intense metabolic control by means of insulin in patients with diabetes mellitus and acute myocardial infarction (DIGAMI 2): effects on mortality and morbidity. Eur. Heart J., 2005, 26(7), 650-661.

[4] Capes, S. E., Hunt, D., Malmberg, K., et al.: Stress hyperglycaemia and increased risk of death after myocardial infarction in patients with and without diabetes: systematic overview. Lancet, 2000, 355(9206), 773-778.

[5] Mublestein, J., Anderson, J. L., Horne, B. D., et al.: Effect of fasting glucose levels on mortality rate in patients with and without diabetes mellitus and coronary artery disease undergoing percutaneous coronary intervention. Am. Heart J., 2003, 146(2), $351-358$.

[6] Lazar, H. L., Chipkin, S. R., Fitzgerald, C. A., et al.: Tight glycemic control in diabetic coronary artery bypass graft patients improves perioperative outcomes and decreases recurrent ischemic events. Circulation, 2004, 109(12), 1497-1502.

[7] Van den Berghe, G. V., Wouters, P., Weekers, F., et al.: Intensive insulin therapy in critically ill patients. N. Engl. J. Med., 2001, 345(19), 1359-1367.

[8] Mehta, S. R., Yusuf, S., Díaz, R., et al., CREATE-ECLA Trial Group Investigators: Effect of glucose-insulin-potassium infusion on mortality in patients with acute ST-segment elevation myocardial infarction: the CREATE-ECLA randomized controlled trial. JAMA, 2005, 293(4), 437-446.

[9] Apstein, C. S., Opie, L. H.: A challenge to the metabolic approach to myocardial ischaemia. Eur. Heart J., 2005, 26(10), 956-959.

[10] Kramer, C. K., Zinman, B., Retnakaran R.: Short-term intensive insulin therapy in type diabetes mellitus: a systematic review and meta-analysis. Lancet Diabetes Endocrinol., 2013, l(1), 28-34.

[11] Wittmann, I.: The potential common mechanism of hormonal resistance, and it's suggested role in pathogenesis of metabolic syndrome and cardiovascular diseases. [Hormonrezisztenciák le- hetséges közös oka és annak feltételezett szerepe a metabolikus szindróma, ill. a cardiovascularis betegségek kialakulásában.] Diabet. Hung., 2014, 22(3), 173-179. [Hungarian]

[12] Reaven, G.: Insulin resistance, type 2 diabetes mellitus, and cardiovascular disease. The end of the beginning. Circulation, 2005, 112(20), 3030-3032.

[13] Graymore, C. N.: Biochemistry of the retina. In: Graymore, C. N. (ed.): Biochemistry of the eye. Academic Press, London-New York, 1970.

[14] Van den Berghe, G.: Insulin vs. strict blood glucose control to achieve a survival benefit after AMI? Eur. Heart J., 2005, 26(7), 639-641.

[15] Libby, P., Plutzky, J.: Diabetic macrovascular disease. The glucose paradox? Circulation, 2002, 106(22), 2760-2763

[16] Ihnat, M. A., Thorpe, J. E., Ceriello, A.: Hypothesis: the "metabolic memory", the new challenge of diabetes. Diabet. Med., $2007,24(6), 582-586$

[17] Gerstein, H. C., Yusuf, S.: Dysglycaemia and risk of cardiovascular disease. Lancet, 1996, 347(9006), 949-950.

[18] Grundy, S. M., Benjamin, I. J., Burke, G. L., et al.: Diabetes and cardiovascular disease. A Statement for Healthcare Professionals From the American Heart Association. Circulation, 1999, 100(10), 1134-1146.

[19] Taskinen, M. R.: Lipid metabolism in diabetes. In: Taskinen, R. (ed.): Diabetes in the new millenium. W. B. Saunders Company, $2000,32-55$

[20] Stern, M. P.: Diabetes and cardiovascular disease. The "common soil" hypothesis. Diabetes, 1995, 44(4), 369-374.

[21] UK Prospective Diabetes Study (UKPDS) Group: Intensive blood glucose control with sulphonylureas or insulin compared with conventional treatment and risk of complications in patients with type 2 diabetes (UKPDS) 33). Lancet, 1998, 352(9131), 837853.

[22] Tattersal, R. B.: Type 2 diabetes or NIDDM: looking for a better name. Lancet, 1989, 333(8638), 589-591.

[23] DeFronzo, A.: Pathogenesis of type 2 (non-insulin dependent) diabetes mellitus: a balanced overview. Diabetologia, 1992, 35(4), 389-397.

[24] Dinneen, S., Gerich, J., Rizza, R.: Carbohydrate metabolism in non-insulin-dependent diabetes mellitus. N. Engl. J. Med., 1992, 327(10), 707-713.

[25] Dinneen, S. F.: Mechanism of postprandial hyperglycaemia in diabetes mellitus. Eur. J. Gastroenterol. Hepatol., 1995, 7(8), 724729.

[26] Lefêbvre, P. J., Scheen, A. J.: Glucose metabolism and the postprandial state. Eur. J. Clin. Invest., 1999, 29(Suppl. 2), 1-6.

[27] Ceriello, A.: The emerging role of post-prandial hyperglycaemic spikes in the pathogenesis of diabetic complications. Diabet. Med., 1998, 15(3), 188-193.

[28] Kahn, B. S., Flier, J. S.: Obesity and insulin resistance. J. Clin. Invest., 2000, 106(4), 473-481.

[29] Winkler, G., Salamon, F., Salamon, D., et al.: Elevated serum tumour necrosis factor-alpha levels can contribute to the insulin resistance in type II (non-insulin-dependent) diabetes mellitus and inobesity. Diabetologia, 1998, 41(7), 860-861.

[30] Taegtmeyer, H.: Cardiac metabolism as a target for the treatment of heart failure. Circulation, 2004, 110(8), 894-896.

[31] Guba, A., Harmancey, R., Taegtmeyer, H.: Nonischemic heart failure in diabetes mellitus. Curr. Opin. Cardiol., 2008, 23(3), 241-248.

[32] Von Bibra, H., St. John Sutton, M.: Diastolic dysfunction in diabetes and the metabolic syndrome: promising potential for diagnosis and prognosis. Diabetologia, 2010, 53(6), 1033-1045.

[33] Horowitz, J. D., Chirkov, Y. Y., Kennedy, J. A., et al.: Modulation of myocardial metabolism: an emerging therapeutic principle. Curr. Opin. Cardiol., 2010, 25(4), 329-334. 
[34] Haffner, S. M.: Abdominal obesity, insulin resistance, and cardiovascular risk in pre-diabetes and type 2 diabetes. Eur. Heart J. Supplements, 2006, 8(Suppl. B), B20-B25.

[35] Kassiotis, C., Rajabi, M., Taegtmeyer, H.: Metabolic reserve of the heart: the forgotten link between contraction and coronary flow. Prog. Cardiovasc. Dis., 2008, 51(1), 74-88.

[36] Soläng, L., Malmberg, K., Rydén, L.: Diabetes mellitus and congestive heart failure. Eur. Heart J., 1999, 20(11), 789-795.

[37] Woodfield, S. L., Lundergan, C. F., Reiner, J. S., et al., for The GUSTO-I Angiographic Investigators: Angiographic findings and outcome in diabetic patients treated with thrombolytic therapy for acute myocardial infarction: the GUSTO-I experience. J. Am. Coll. Cardiol., 1996, 28(7), 1661-1669.

[38] Simon, K., Surek, R., Szamosi, I., et al.: The role of non-ischemic diabetic cardiomyopathy in pathogenesis of the increased cardiovascular risk. [A nem iszkémiás diabeteses cardiomyopathia szerepe a fokozott cardiovascularis kockázat elóidézésében.] Cardiol. Hung., 2011, 4l(3), 200-205. [Hungarian]

[39] Hunt, K. J., Resendez, R. G., Williams, K., et al.: National cholesterol education program versus Wold Health Organization metabolic syndrome in relation to all-cause and cardiovascular mortality in the San Antonio Heart Study. Circulation, 2004, $110(10), 1251-1257$.

[40] Opie, L. H.: Metabolism of free fatty acids, glucose and catecholamines in acute myocardial infarction. Relation to myocardial ischemia and infarct size. Am. J. Cardiol., 1975, 36(7), 938-953.

[41] Landray, M. J, Toescu, V., Kendall, M. J.: The cardioprotective role of $\beta$-blockers in patients with diabetes mellitus. J. Clin. Pharm. Ther., 2002, 27(4), 233-242.

[42] Bristow, M.: Antiadrenergic therapy of chronic heart failure. Surprises and new opportunities. Circulation, 2003, 107(8), 11001102.

[43] Wallbaus, T. R., Taylor, M., DeGrado, T. R, et al.: Myocardial free fatty acid and glucose use after carvedilol treatment in patients with congestive heart failure. Circulation, 2001, 103(20), 24412446.

[44] Shakar, S. F., Lowes, B. D., Lindenfeld, J., et al.: Peak oxygen consumption and outcome in heart failure patients chronically treated with $\beta$-blockers. J. Card. Fail., 2004, 10(1), 15-20.

[45] Bell, D. S.: Advantages of a third-generation $\beta$-blocker in patients with diabetes mellitus. Am. J. Cardiol., 2004, 93(9 Suppl. 1), $49-52$.
[46] Essop, M. F., Opie, L. H.: Metabolic therapy for heart failure. Eur. Heart J., 2004, 25(20), 1765-1768.

[47] UK Prospective Diabetes Study (UKPDS) Group: Effect of intensive blood-glucose control with metformin on complications in overweight patients with type 2 diabetes UKPDS 34.) Lancet, 1998, 352(9131), 854-865.

[48] Krentz, A. J., Bailey, C. J.: Oral antidiabetic agents. Current role in type 2 diabetes mellitus. Drugs, 2005, 65(3), 385-411.

[49] Hanefeld, M., Cagatay, M., Petrowitsch, T., et al.: Acarbose reduces the risk for myocardial infarction in type 2 diabetic patients: meta-analysis of seven long-term studies. Eur. Heart J., 2004, 25(1), 10-16.

[50] Chiasson, J. L., Josse, R. G., Gomis, R., et al., for The STOP-NIDDM Trial Research Group: Acarbose for prevention of type 2 diabetes mellitus. The STOP-NIDDM randomised trial. Lancet, 2002, 359 (9323), 2072-2077.

[51] Beckman, J. A., Creager, M. A., Libby, P.: Diabetes and atherosclerosis. Epidemiology, pathophysiology, and management. JAMA, 2002, 287(19), 2570-2581.

[52] Adler, A. I.: Cardiovascular risk reduction in diabetes: underemphasised and overdue. Messages from major trials. Clin. Med., 2001, $1(6), 472-477$.

[53] Haffner, S. M., Mykkänen, L., Festa, A., et al.: Insulin-resistant prediabetic subjects have more atherogenic risk factors than insulin-sensitive prediabetic subjects. Implications for preventing coronary heart disease during the prediabetic state. Circulation, 2000, 101(9), 975-980.

[54] Gaede, P., Vedel, P., Larsen, N., et al.: Multifactorial intervention and cardiovascular disease in patients with type 2 diabetes. N. Engl. J. Med., 2003, 348(5), 383-393.

[55] Han, W., Chuang, K. H., Chang Y. T., et al.: Imaging metabolic syndrome. EMBO Mol. Med., 2010, 2(6), 196-210.

(Simon Kornél dr., Siófok, Semmelweis u. 1., 8600 e-mail: simonkorneldr@t-online.hu) 